\title{
The View from Northeastern Europe: The Baltic States and the Russian Regime
}

\section{By James S. Corum}

\section{Introduction}

If one wants to understand what is going on in Russia and also to look at the most likely main confrontation points between the West and Putin the three Baltic States are the best place to start. The three Baltic States of Estonia, Latvia and Lithuania are not well known to most Western leaders or academics but these small countries are a special place to understand modern Russia and its politics. The Baltic republics were not only under Soviet domination, like so many of new East European NATO allies, but they were part of the USSR from 1940 to 1991. They had to learn Russian (all the people today over 40 are generally fluent in Russian) and the older generation had to serve in the Soviet military, As one Latvian general who listens to Russian news daily told me, "Unlike the Poles, Hungarians and Czechs who at least had nominal independence and some of their own institutions we (Baltics) were part of the USSR-we were on the inside - and we KNOW these people."

Only twenty four years ago the three Baltic States were impoverished republics of the USSR. The historical memories of the USSR and the KGB and the gulags are all very fresh. Although the Baltics have suffered greatly as people, the people of Latvia, Estonia and Lithuania are not crippled by their historical experience. The majority of the Baltic populations certainly have no liking for the Russians but they coexist with them. Baltic Businesses are mainly focused on the West, but they do considerable business with the Russians, especially in terms of importing energy and raw materials and serving as a transport conduit to Russia from the West. The Baltic populations coexist, generally very peaceably, with large Russian ethnic populations that are a legacy of the Russian population movements after World War II. Finally, the Baltic populations feel considerable security in belonging to NATO and the European Union and their attitude towards the Russians is realistic. It's their neighborhood and they know they have to exist as small and prosperous and democratic states next to a very large third world (in most respects of living standards), aggressive and dictatorial neighbor.

English is now the common language of the Baltic young people and the businessmen and academics, but Russian is still widely understood and spoken among the over-40 generation (who had to learn it in school from a young age). The Baltics follow the Russian media closely 
(when I lived in Tartu Estonia, one hour from Russia, I had 12 Russian channels on cable TV) and read Russian books. Many of the Baltic leaders travel to Moscow on business and high school students travel as tourists to nearby St. Petersburg. The Baltic States have world class universities (Tartu University, Tallinn Technical University, University of Latvia in Riga, University of Vilnius etc. are exceptional modern universities with very high entry standards) with some of the top Russian studies faculties in Europe.

After more than five years of living in the Baltics and working with their academics I can say that the Baltic governments are all highly realistic in that they understand the reality of small democratic nations facing a powerful and highly aggressive dictatorship and the need for allies. The Baltic States populations believe, for very good reason, that they face an existential threat from Russia, a nation that intensely resents the fall of the Soviet Empire and whose leaders are working to restore a new version of the Soviet Empire in which the Baltic States and all former republics will have a place clearly subordinate to Russian interests.

This chapter will examine the view of Russia and the Putin government from the viewpoint of the Baltic States and focus on the key areas of friction between the Baltic States and Russia.

\section{The Weight of History}

History is key to understanding the Baltic and Russian relationship and the relationship with the West. First of all, while the Baltic States are geographically in Eastern Europe, in terms of culture, economic relationships, religion and political development they are thoroughly Western European. The Baltic relationship with the West began in the late $12^{\text {th }}$ century with the arrival of merchants, missionaries and crusaders from Germany, Denmark and Sweden. The Baltic regions were inhabited by Baltic pagan tribal peoples (ancestors of the Latvians, Prussians and Lithuanians) and Finno-Ugric peoples (ancestors of the Finns and Estonians). By the 1240s a group of small states and dioceses had been created in Latvia and Estonia (Livonia) with the local tribes converted to Christianity (some voluntarily, some not) and with a German speaking upper class ruling the locals who included assimilated local rulers as well. Led by Hansa cities which tied the Baltics to trade with Europe, Latvia and Estonia became prosperous. Lithuania developed separately and remained Europe's last pagan kingdom until it accepted Catholic 
Christianity in 1386 and tied itself by marriage to the Polish dynasty. Along with Finland, the Baltic region developed as an integral part of the West in the middle ages in terms of religion (Catholic, not Orthodox), its political relationships (tied to the Swedish and Danish Kingdom and German Empire), and economics - tied mainly to Germany with as the lingua franca of the Baltic states.

After the state of the Teutonic Knights came apart in the sixteenth century Estonia and Latvia became Lutheran and came under the Swedish Empire. In the $18^{\text {th }}$ Century, under Czar Peter the Great, Estonia and Latvia conquered by the Russians. At the end of the $18^{\text {th }}$ Century Lithuania was conquered by Russia and the Duchy of Kurland (Kurzeme in modern Latvia) were absorbed by the Russian Empire. But in the period under Russian control the Baltic countries developed very differently from the rest of Russia. From the beginning of the Russian takeover the provinces of Estonia and Latvia were granted autonomy under the Czar with a council of ethnic German barons ruling the region. When Finland was taken from Sweden by the Russians in 1809 it was, in a similar fashion, granted autonomy as a grand duchy and ruled by an indigenous nobility. Both Finland and Livonia, as Lutheran and culturally Western, looked to the West in terms of trade and culture. Estonia and Latvia became the richest and most advanced provinces of the Russian Empire with universal literacy in the region by 1800 (150 years before Russia had universal literacy), and with serfdom abolished more than 40 years before Russia. Lithuania remembered its long history as an independent state and duchy associated with Poland and, along with the Poles, initiated several major nationalist rebellions in the $19^{\text {th }}$ century. These were, of course, suppressed with utter ruthlessness by the Russians but failed to quench the desire for independence. Under self-rule, Estonia and Latvia developed more peacefully and by the $19^{\text {th }}$ century the Baltic provinces and Finland had an indigenous middle class, extensive trade with the West, and was the first region of Russia to become industrialized.

Yet, through the period of Russian control there was constant friction between the Baltic peoples and the Russians largely to the prosperity of the Baltic peoples vis a vis the generally poorer Russians and also over the significant role that the Baltic nobility played in running the empire. Just read War and Peace to see the friction between the Marshal Barclay de Tolly, commander in chief of the Russian Army in 1812 and an ethnic German from Estonia, and the ethnic Russian 
officers who view de Tolley and his largely Baltic staff with considerable distrust as "Germans" who might not be fully trustworthy and committed to the defeat of Russia's enemies.

Latvia and Estonia, along with Finland, became the most modern, literate and advanced regions of the Old Russian Empire. In the nineteenth century the Baltic peoples also developed an impressive indigenous literature and strong sense of nationalism. The Baltics retained their languages and national culture as very separate from the Russian culture. The Latvian, Lithuanian and Estonian languages (none of which are Slavic) all use Latin letters, not Cyrillic. With the collapse of the Russian empire in 1917 the three Baltic States and Finland formed indigenous Western style governments and with Western help (German and British help mostly) defeated the Red Army in a series of bloody independence wars. ${ }^{2}$ Russia, soon to become the Soviet Union, reluctantly accepted reality and recognized the three Baltic States and Finland as independent nations. However, the Soviets remained bitter and hostile towards the Baltic republics and the interwar period saw some blatant acts of aggression against the Baltic countries to include a failed attempt by Soviet agents to overthrow the Estonian government by a coup at Christmas 1924.

In the twenty years of peace following the end of the independence wars saw the three Baltic nations develop as modern Western countries with some measure of prosperity, in contrast to the violence, collectivization and poverty prevalent in Russia under Stalin. However, in 1939 the fate of the small republics was sealed by the Molotov-Ribbentrop Pact of August 1939 that divided Europe into spheres of influence to be controlled by Stalin and Hitler. The three Baltic States were part of Europe designated as the soviet sphere of influence, along with Eastern Poland, part of Romania and Finland. The Soviet Union was given the green light by Hitler to annex those regions. Stalin immediate invaded Finland in November 1939 and after a brief and bloody war succeeded in annexing some major parts of Finnish territory. At the same time as invading Finland Stalin pressured the Baltic States into allowing large Soviet military bases in their countries. The West, at war with Hitler and fearful of antagonizing Hitler's key ally, did nothing to counter this naked aggression against small democratic states. In June 1940 the neutral and militarily weak Baltic States were invaded and occupied by Stalin's forces. The Baltic governments were dissolved, the national leaders arrested and murdered. After phony elections 
the three nations were annexed as part of the Soviet Union and became republics of the Soviet Union. ${ }^{3}$

\section{The Baltics as Western Nations - The Weight of History}

By June 1940 the neutral and militarily weak Baltic States were invaded and occupied by Stalin's forces. The Baltic governments were dissolved, the national leaders arrested and murdered. After phony elections the three nations were annexed as part of the Soviet Union and became republics of the Soviet Union. ${ }^{4}$ Under Soviet domination the three Baltic States suffered horrendous oppression as the national elites were either murdered or sent to the Gulags. Collectivization and nationalization of farms and industries and businesses imposed. Large sectors of the population to include priest and ministers, businessmen, many professionals, intellectuals, military officers and landowners were marked down for down for mass arrest and deportation. ${ }^{5}$ The only respite came from the German invasion of the Soviet Union in June 1941 that quickly overran the Baltic States and placed the countries under German control until 1944. The Baltic peoples, who had long resented German rulers and who had kicked the Germans out in 1919, viewed the Germans as the lesser of two evils and a considerable number of Latvians and Estonians fought alongside the Germans during the World War. ${ }^{6}$ The fact that the Baltics had fought so eagerly, and very well, against the Soviet State remains one of the main points of friction between the Baltic States and the Russians today.

After the Soviets reestablished power in the three Baltic States there were massive waves of repression lasting until the death of Stalin in $1953 .^{7}$ This period was characterized by mass arrests and the deportation of hundreds of thousands of Lithuanians, Latvians and Estonians either to the gulags or Siberia. ${ }^{8}$ The Baltic peoples strongly resisted and large nationalist resistance movements were formed in the Baltic States. For almost a decade after the end of World War II the Soviets faced anti-communist guerrilla forces, called the "Forest Brothers," in the rural areas of the Baltic States. Not until 1953, after major efforts by the KGB and military, were the Forest Brothers effectively suppressed. ${ }^{9}$ Repressing the Baltics was a bloody conflict that lasted for years and resulted in tens of thousands of casualties. The wave of soviet repression, that targeted the whole societies including the farmers, small businessmen, professionals, and clergy, touched virtually every family in the Baltic States. Most Baltic 
families can recall a father who was jailed, an uncle who disappeared in the Gulags, or a grandfather sent to Siberia. The memories are still fresh.

The rest of the Soviet era was one of forced communization and repression. Because the three Baltic States were far more economically advanced than Russia, the three countries became a center for Soviet high tech and military industries. Thousands of Russian workers were brought into Latvia and Estonia to work in the military complexes. The northeastern corner of Estonia was declared an area of military industry and cleared of Estonians, who were deported and replaced by Russians. Large numbers of Russians were also settled to work in industries in Latvia. Only Lithuania escaped the large scale influx of Russian workers, largely because the nationalist guerrillas caused so much trouble in rural areas that Stalin's plans to settle large numbers of Russians on collectivized land were foiled. ${ }^{10}$

In the late 1980s, when Premier Gorbachev announced reforms in the USSR, the Baltic peoples responded with organizing non-communist political parties (quite illegal even under Gorbachev) and initiating mass demonstrations opposing Soviet rule. The moist dramatic expression of Baltic nationalism and yearning for democracy came in August 1989 when, on the fiftieth anniversary of the Molotov-Ribbentrop Pact more than two million Baltic citizens formed a human chain several hundred kilometers long through the three states. The chain began in Tallinn Estonia, wound through Riga, Latvia and ended in Vilnius, Lithuania. On this day the Baltic peoples celebrated their national pride and thousands flew their national flags that they had secretly made- a criminal act in the Soviet Union. It was the largest peaceful mass demonstration in history. Whatever the local communist leaders had told Moscow, the Baltic human chain was clear proof that most Baltic peoples saw the Soviet Union as an occupying force.

The desire for the Baltic peoples to have an honest account of their relationship with the USSR resulted in the Soviet government agreeing to a commission of Baltic and Russian historians to examine the events of 1939 and 1940. For the first time, the Russians acknowledged the secret clauses of the pact Molotov Ribbentrop Pact and the People's Congress of the USSR in December 1989 voted to denounce the secret Soviet/Nazi protocols as unjustified and invalid under international law. ${ }^{11}$ Of course, this acknowledgement completely undercut any legal or moral foundation for the USSR to retain the Baltic States as subject republics and the 
independence movement in the Baltic States progressed to open calls for the renewal of their independence.

In defiance of the USSR Lithuania declared its independence in 1990 and held free elections as KGB troops tried to suppress the new government in Vilnius in January 1991. Bloody repression attempts in Latvia and displays by Soviet forces in Estonia were met with and an overwhelming public mobilization against the Soviet government in all three Baltic States. Baltic militia units were formed spontaneously and deployed to protect the newly elected national parliaments, town councils and other new democratic institutions. Free elections resulted in democratic and anticommunist governments and national referenda in all three countries overwhelmingly supported full independence. With the failed coup of August 1991 and the collapse of the Soviet Union the three Baltic States all officially proclaimed independence and were soon recognized by the Western nations

\section{The Baltic States opt for the West}

The reform government in Moscow under Boris Yeltsin that followed the 1991 coup recognized the Baltic States as independent nations and for a brief period the Russians and Baltic States tried to establish friendly state to state relations. For a brief period in the 1990s Russia and the Baltic States maintained cordial relations. The main thing for the new Baltic democracies was to negotiate the withdrawal of all the Russian military bases in the three Baltic States, of which there were many. The complex negotiations resulted in the withdrawal of the Russian forces and the turnover of bases to the national governments in 1994.

In 1997 Russia attempted to negotiate a long term arrangement with the Baltic States with security guarantees and economic ties to Russia in an attempt to keep the Baltic States neutral and far away from NATO. Given the history of Russian guarantees the Russian proposals were rejected out of hand and this resulted in some unpleasant diplomatic and economic friction between Russia and the newly independent states. ${ }^{12}$

In realistic terms, however, what positive things could Russia offer the Baltic States? Russia was broke and suffering from economic and social crisis. The idea of relying on the security and protection from a government that had recently killed unarmed Baltic citizens in the independence demonstrations of 1990 and 1991 and was developing into an authoritarian mafia 
state was ludicrous. From a deep knowledge of Russia and the Russians, the Baltic peoples know that there was nothing from the old system of the USSR that was worth retaining and there was nothing that the new Russia might offer except for cheap energy. When the Baltic States regained independence they immediately chose a path of Westernization of politics, economics and defense. Estonia, Latvia and Lithuania adopted democratic constitutions and parliamentary states, all opted for capitalist market economies with laws on the model of the US and Western Europe, and they created new armed forces from scratch, all on a Western/Nordic model and equipped with Western weapons and Western doctrine.

The wisdom of rejecting any long term connections with Russia to support an illusion of continued empire and turning completely to the Western model of government and economics is evident in the dramatic economic and social progress that some Eastern European countries and the three Baltic States made after the fall of the Soviet Empire. The countries that took the decision from the start to move fully Western (Poland, Hungary, Czech Republic, Slovakia and the three Baltic States have become stable and prosperous since 1991. On the other hand, the countries that were unwilling to take the plunge towards full democratization and Western economics and retained a close association with Russia have been mired in authoritarianism and poverty. Starting from a relatively equal level of per capita income in 1991 some Eastern European and Baltic States enjoyed very high economic growth rates and have made rapid progress towards a Western European living standard while Russia aligned nations continue to lag in every standard. One need only to compare the World Bank data (2013) on per capita income (GNI) to see that Russia offers nothing positive to countries aligned with it. The GNI for Poland was \$12,960, Estonia \$17,370, Latvia \$15,280, Lithuania \$14,900. Contrast this with the GNI for Russia’s close ally Belarus $(\$ 6,720)$ and the Ukraine (\$3960), a country that only last year began the move to Westernize. Even oil rich Russia lagged behind the three Baltic States with a GNI of $\$ 13,860$.

The Baltic States initially proclaimed a policy of neutrality until the withdrawal of the last Russian forces from the Baltic nations in 1994. With this accomplished all three nations proclaimed their goal of complete political and economic integration with the West and proclaimed their goal to join the NATO alliance. ${ }^{13}$ The desire to rejoin the West was not a rejection of their history but a fulfillment of it as the Baltic States see themselves as 
fundamentally Western in national culture - despite their eastern geography. The goals of joining NATO and the EU were treated with considerable skepticism in the US and Western Europe, but from the mid-1990s the Baltic States made a concerted effort to develop economic and security policies and institutions that met the NATO and EU standards. ${ }^{14}$ Most significantly, the Baltic States have made an impressive effort to visibly support the West in military operations. All three Baltic countries have sent troops to operate under US and NATO command in the wars in Iraq and Afghanistan. Unlike some other NATO allies and major US partners, the Baltic States have sent combat troops and have not placed caveats on the use of their forces in combat. In Afghanistan the commitment was significant, with more than 750 Baltic States personnel serving there in 2010 and including Estonian and Latvian infantry companies and Lithuanian Special Forces as well as support personnel and personnel to man a provincial reconstruction team. The Baltic States have also suffered casualties while fighting at the side of the US. ${ }^{15}$

\section{Putin's Russia tries to rewrite history-- Again}

Any positive developments in Russian/Western relations ended in 2000 with the rise of Vladimir Putin as leader of the Russian state and liberalization measures and tentative steps towards open government and democracy were systematically squashed. One of Putin's main concerns has been supporting a new Russian nationalist version of history, which is essentially the old Soviet line. Under the current Russian regime history has again been relegated to the role of serving the state. The tone and substance of Russian state history publications since 2000-- and almost all scholarship is under the control of the state and state allied agencies-- is one of aggressive nationalism. This aggressive nationalism also includes a virulent anti-Baltic theme and a resounding defense of the Soviet takeover and occupation of the Baltic States after 1940. In the history promoted by the Russian government under Putin the official view is that the Soviet occupation of the Baltic States was fully justified and those Baltic claims of Soviet crimes against humanity (which are carefully documented and detailed by national commissions in the Baltic States) are exaggerated. The Russian historical approach under Putin is to portray the Baltic peoples as all Nazi supporters in World War II and that any critique of the Soviet Union and its role in the Baltics is a "revival of fascism."16 Baltic attempts to publish accurate histories and to gain international recognition of the crimes committed against the Baltic peoples have 
been met by a Russian information war to discredit the Baltic States internationally. In 2005 Kremlin's European affairs chief Sergei Yastrzhembsky rejected the findings of the 1989 historical commission and the subsequent resolution of the Soviet government on the legality of the Soviet occupation of the Baltic States in 1940. The Kremlin insisted that the Soviet occupation of the three states was done with the approval of the Baltic governments. ${ }^{17}$ In 2009 Prime Minister Medvedev set up a commission to combat the "falsification of history" that shows the Soviet regime in a negative light. ${ }^{18}$ This is in accord with the new Russian history of the Putin era that now portrays Stalin in a positive light as a great national leader and commander One of the key themes of the official Russian media is to depict the Baltic peoples of the 1930s and 40s as "Nazis" and to insist that the Baltic peoples remain deeply "Nazi" in orientation, thus legitimizing overt Russian hostility in the past and present. The Western support for the Baltic States thereby becomes open support for the return of Nazism. For example, a Russian News Service denunciation of a film about the Latvians in World War II states, "One wonders if the filmmakers stressed the fact that ethnic Latvians were amongst the most enthusiastic and willing collaborators with the Nazis during World War II.... The US government is supporting Nazi revisionists in Riga (and in Tallinn, Kiev, and Zagreb as well). How low have we fallen?"19 Russian media cartoons of 2014 show depictions of Latvia with a Hitler and Nazi flag and the Russian state media runs articles such as "Estonian could become a Haven for the Nazis around the World". ${ }^{20}$ The characterization of all Eastern European, and especially the Baltics, as Nazis is a regular theme stressed by Putin. In October 2014 Putin argued that "open neo-Nazism" has become commonplace in the Baltic States with the Ukraine as an especially egregious example of neo Nazism. ${ }^{21}$ The Latvian Foreign Ministry replied that Putin was waging an "information war" against the Baltics and other European states. ${ }^{22}$

Putin's feelings on the interpretation of history are not a new development. In 1994, long before he came to power, at a meeting in Hamburg attended by Putin the Estonian President Lennart Meri referred to the Russians as "occupiers" and Putin dramatically stood up and led the Russian diplomats out of the conference. ${ }^{23}$ The state supported Russian media today publishes books insisting that the occupation of Lithuania under Stalin was a voluntary act endorsed by Lithuanians and that the occupation of Lithuania in 1940 and after World War II was legal and proper. These Blatant falsifications of horrendous crimes against humanity are clearly irritating 
to the Lithuanian and Baltic peoples. But the Baltic governments understand that the actions by Russia are essentially part of a long term information campaign to delegitimize the Baltic States in the eyes of the world and to whip up the feelings of the ethnic Russian population in the Baltic States and to encourage the belief among the Russian population that the Baltic States are an imminent threat to Russia. Finally, the Putin regime's information campaign against the Baltic States is meant to encourage the hostility of the Russian public and alert them to the Baltic threat, which can only be properly resolved if the Baltics revert to a status of being within the Russian sphere of influence as a subject state - something on the status of Belarus. In the state propaganda it is Russia's policy to style itself as the protector of ethnic Russians outside of Russia, which is one of the major themes of the books of Project Russia, the ideological expression of the Putin regime. ${ }^{24}$

In support of the ethnic minorities of Russians within the three Baltic States Russia generously subsidizes ethnic Russian groups and political parties and local Russian television programs. The propaganda of the Russian regime is prominent in all three Baltic States where it is viewed by the Russian minorities who, to a large degree, refuse to assimilate as Baltic citizens. Information warfare, conducted over the long term, is a Russian specialty and many of the old Soviet propagandists are now working in the service of the Russian state. In fact, the old Soviet media and propaganda organizations simply changed their names and operate today much like in the Soviet era - down to many of the old Soviet propaganda themes. Indeed, Russia has conducted a media campaign against Georgia, Moldova and Lithuania in times when Russia wanted to coerce those countries to accept Russian policies. ${ }^{25}$ The non-Russians are fully aware of the content of the Russian programming and press as Baltic people over 40 generally speak fluent Russian. ${ }^{26}$

\section{Russia and the Ethnic Russians in the Baltics}

When the USSR occupied the Baltic States it initiated a policy of mass deportations of Baltic peoples and the resettlement of ethnic Russians into Latvia and Estonia especially. In the 1960s and 1970s many ethnic Russians moved into the Baltic States to work in the military industries. Where, in 1940, the populations of the Baltic States were almost all indigenous but by the end of Soviet rule large Russian minorities were established. For example, in 1935 Latvia had a 
population of 1.48 million ethnic Latvians and 206,000 Russians, in 1989 the population was 1.388 million ethnic Latvians and 909,000 Russians. ${ }^{27}$ Estonia, which had only a handful of ethnic Russians in 1940 had a Russian ethnic population of $23 \%$ by 1991 . Almost all ethnic Russians remained in the Baltic States after independence of 1991, preferring life as non-citizens in the Baltics to life in Russia. Latvia and Estonia have significant Russian ethnic minorities that are not well assimilated into the national population. ${ }^{28}$ Although ethnic Russians in Latvia and Estonia can become full citizens by a simple naturalization process that requires only a five year legal residency and learning the national language, many ethnic Russians refuse to assimilate at The Russian ethnics who remain in Estonia and Latvia have permission to live there and to vote in local elections, but as non-citizens, they cannot vote in national elections. ${ }^{29}$

The Russian information campaign against the Baltic States is, to a large degree directed to ethnic Russians living in the Baltics as well as the general population of Russia. The Putin regime sees the ethnic Russian populations as a useful fifth column to undermine the three States from within and who would naturally ally with Russia, or provide an excuse for Russian intervention, should a conflict between Russia and the Baltic States heat up.

The role of history has played a big role in ethnic tensions as the Baltic governments, representing the feelings of the great majority of their populations, have taken down or moved communist era memorials that represent the most horrible events of their history. For the Russian ethnic minority, however, the memorials to the Red Army and its occupation of the Baltic States are a reminder of the glory days of Soviet history. In 2007 the Estonian government's attempt to move a memorial to the Red Army in Tallinn provoked a violent response from mobs of ethnic Russians. Both Tallinn and the heavily Russian northeast region witnessed days of violent demonstrations and violence that resulted in one death. ${ }^{30}$ In Latvia and Estonia there have been other incidents of mob violence connected with the Russian minorities. Lithuania is peaceful in this regard with only six per cent of its population ethnic Russian. However, the role of interpreting history also plays a very important role in the Lithuanian relationship with Russia and there is considerable bitterness as well between Russian and Lithuanians over the period of Soviet occupation. ${ }^{31}$ 
Unfortunately, several Russian opinion polls show the success of Putin's information campaign towards the Russian population in portraying the Baltic States as a threat to Russia. Latvia and Lithuania are seen as two of the three nations most hostile to Russia in national opinion polls, and Russian opinion polls in 2007 showed that $42 \%$ of Russians saw Lithuania as "very hostile" to Russia. ${ }^{32}$ On the other hand, Putin is likely to be fooling himself if he believes that the ethnic Russian populations in the Baltic States might actively serve as a fifth column to help Russian ambitions to neutralize or reoccupy the Baltic States. While the ethnic Russians in Estonia or Latvia might take some pride in Putin and voice support for the Russian invasion of the Ukraine, few would choose to live in Russia or to see their present situation changed. After all, the ethnic Russians of the Baltic States enjoy a far higher living standard than they would in Russia, far better social services and benefits, full political freedom, and better pay and opportunity than one finds in a depressed, third world Russia. Finally, their status as EU residents allows them complete freedom of movement in the EU and to foreign countries. Some of the ethnic Russians can be overly nationalistic, but most realize they have a good deal under the present situation. Over time ethnic tension will diminish with the aging of the large Russian work force that was brought into Latvia and Estonia in the Soviet era and the ongoing assimilation of their children, who, unlike their parents, learn the national languages and are more integrated into the social and economic life of the country. ${ }^{33}$

\section{Security Concerns}

All three Baltic States have faced aggressive actions from Russia in the last decade. Estonia in April and May 2007 faced a large scale highly organized cyber-attack that was designed to take down the government websites and the websites and communications of the banks and large businesses. This coordinated attack was most likely the work of Russian groups, although the Russian government denied any involvement. ${ }^{34}$ The Lithuanians, almost completely dependent on Russian energy supplies, are made to pay the highest energy costs in the European Union. What is most disconcerting is the ratcheting up of open hostility against the Baltic States expressed in the highest levels of Russian leadership. In 2013 Vladimir Zhirinovsky, Deputy Speaker of the Russian Federation State Duma, stated, "Let the puppies (referring to Latvia) bark in the world, eventually they will be occupied. ...The entire Baltics will be either occupied or destroyed.... definitely." ${ }^{35}$ Alexandr Dugan, Professor University of Moscow and a leading 
ideologue of the Russian regime, referred to the Baltic States in a recent interview and noted, "Russia considers them an enemy, and makes no special distinctions between them. This view is shared by the elite, including the liberals, and general population. Russia is waiting for a global redistribution of power (in the world). For example, should something happen to the U.S., we will immediately re-occupy these countries. We will accomplish this either peacefully or by force. We have already applied some of the methods to create serious internal problems in Estonia and Latvia.“36

The Baltic States response have been restrained to such open threats to their independence, partly because they are members of NATO and partly because they know that in their position as small countries that it might be best to refrain from criticizing the Americans or Western Europeans until it really matters. Unlike the American government or Western Europeans governments, the Eastern Europeans and the Baltic countries, realize that there was never any "reset" with Russia. Indeed, the situation has become much worse since the Obama administration announced its "reset' with Russia and outlined a future of closer cooperation. While the US and NATO talked of closer cooperation with Russia from 2009 to 2014, and NATO refrained from listing Russia as a threat, the last three Russian military doctrines promulgated since 2003, the last approved in 2010, all explicitly state that NATO is Russian's enemy and sees the expansion of NATO into the Baltic States as one of the main threats to Russia. ${ }^{37}$

Within the European Union (all three Baltic republics are members) there has been a reluctance to challenge the Russian aggressive actions in any meaningful way. Generally, the three Baltic States have been fairly quiet in the EU for fear of upsetting the larger Western European nations, notably Germany, who are still committed to a closer relationship to Russia. Within the European Union the three Baltic States want to be seen as modern and cooperative nations and for this reason have been muted in pushing the EU to stronger actions against Russia, as such it would only lead to increased friction with Germany, which is a key Baltic trading partner, and not likely to succeed. ${ }^{38}$ 
There is an almost universal consensus among the Baltic government leaders and military (and public) that Russia is a direct threat to their existence and that, as small nations, the only sure assurance of their freedom is the defense guarantees of the US through NATO. On the other hand, there is a definite fear of sounding alarmist and thus irritating the US administration by any overt critique of US policy, or lack of policy, to face Russian aggression in Eastern Europe ${ }^{39}$ Therefore, the Baltic States have quietly worked through NATO to lobby for a realistic view of Putin's Russia. In the run-up to NATO's publication of the new NATO strategic concept in 2009 and 2010 the three Baltic States In the run-up to NATO crafting a new strategic concept, the three Baltic States, along with the Eastern European NATO members, mounted a quiet but effective lobbying effort to influence the new NATO Strategic concept to ensure that it would recognize the ongoing strategic threat of Russia and that NATO would maintain its focus on conventional military deterrence. ${ }^{40}$ In this the intensive Baltic lobbying effort was successful in that NATO did reaffirm territorial defense of the member states as a core mission of NATO. Still, the Obama administration and its pivot away from Europe and the ongoing US force cutbacks in Europe in the face of Russian military increases, as well as its reluctance to make a serious response to the Russian invasion of the Crimea and Eastern Ukraine have left the Baltic nations very worried about the long term commitment of the Americans.

\footnotetext{
${ }^{1}$ The author worked in the Baltic States for the Baltic States from January 2009 to June 2014 as Dean of the Baltic Defence College, the higher military education college of the three Baltic States. In that position I worked closely with senior military and political leaders and academics of the three Baltic States. I lived and worked in Estonia, but my job took me regularly through all parts of the Baltic States. Much of this article is based on the author's personal experience on working for and with the Baltic armed forces.
} 
${ }^{2}$ Andres Kasekamp, A History of the Baltic States, (London: Palgrave, 2010) pp. 99-105. Kasekamp provides the best general history of the Baltic States in English.

${ }^{3}$ Ibid pp. 128-131.

${ }^{4}$ Ibid

${ }^{5}$ All the Baltic States have established historical commissions to document the victims of the Soviet period of occupation. All three states have published extensive detailed studies of the Baltic citizens killed, exiled, arrested or sent to prisons. In many cases the outcome is fuzzy with a known arrest date but nothing thereafter. Nevertheless, the enormous scale of Soviet repression and crimes against humanity committed against the Baltic States over 50 years have been very well documented. For details on the Soviet repression in Estonia in 1941-1945 see Estonian International Commission for the Investigation of Crimes Against Humanity, Estonia 1940-1945 (Tallinn: Estonian Foundation for the Investigation of Crimes Against Humanity, 2005).

${ }^{6}$ Latvia provided two divisions to the German Army, the $15^{\text {th }}$ and $17^{\text {th }}$ Waffen SS Divisions and the Estonians manned the $20^{\text {th }}$ Waffen SS Division. The Western Allies after the war during the Nuremberg Trials determined that the Baltic military formations were not criminal organizations and had not committed war crimes.

${ }^{7}$ Kasekamp. pp. 141-146.

${ }^{8}$ In one wave of deportations in three days in March 43,000 Latvians, including women and children, were rounded up and deported to Siberia, where many perished. In just this one wave of deportations 92,000 Baltic people were sent to Siberia. In all, hundreds of thousands of people from these small states were sent to the Gulags and to settlements in Siberia and Central Asia. See Paul Rothenhäusler and Hans-Ueli Sonderegger eds., Errinerung an den Roten Holocaust (Rothenhäusler Verlag: Stäfe Switzerland, 1999) see pp. 58-69.

${ }^{9}$ For details on the suppression of the Latvians see Janis Straume, Lettland im 2. Weltkrieg (Riga: Nacionālais Apgāds,2007) pp. 41-46.

${ }^{10}$ For a detailed analysis of the largest and most effective resistance movement in the Baltics see Vylius Leskys, "Forest Brothers" 1945: The Culmination of the Lithuanian Partisan Movement," Baltic Security and Defence Review vol. 11, No. 1, 2009.

${ }^{11}$ On the history commission that revised the Soviet history of the 1939 Pact see Heike Lindpere, MolotovRibbentrop Pact: Challenging Soviet History (Estonian Foreign Policy Institute: Tallinn, 2009) On the Soviet denunciation of the treaty's legality see pp. 173-195.

${ }^{12}$ See Zaneta Ozolina, "Crisis Prevention or Intervention: Latvia's Response to the Proposed Russian Security guarantees," in Crisis Management in a Transitional Society: the Latvian Experience, eds. Eric Stern and Dan Hansen, (Stockholm: Forsvarshogskollan, 2000) pp. 188-215.

${ }^{13}$ On Baltic States economic reforms in the 1990s see Kasekamp pp. 181-183.

${ }^{14}$ Kasekamp, pp. 183-185.

${ }^{15}$ For a study of the deployments of the Baltic forces in service of NATO see James S. Corum, The Development of the Baltic Armed Forces in Light of Multinational Deployments (Carlisle PA: US Army War College Strategic

Studies Institute, 2013).

${ }^{16}$ Kasekamp p. 196.

${ }^{17}$ BBC News 5 May 2005 "Russia denies Baltic Occupation."

${ }^{18}$ Kasekamp. p. 197.

${ }^{19}$ Voice of Russia World Service, http://www.ruvr.ru/main.php?lng=eng\&q=25586\&cid=59\&p=12.04.2008

${ }^{20}$ http://www.newsru.com/russia/30oct2011/margelov.html. “ Эстония может стать прибежищем для нацистов со всего мира. Маргелов подбивает Эстонию дать убежище уцелевшим нацистам со всего мира".

${ }^{21}$ Damian Sharkov, "Putin Warns of Neo-Nazism in Ukraine and Europe Ahead of WW2 Memorial, Newsweek, 15 October 2014.

${ }^{22}$ Ibid.

${ }^{23}$ Masha Gessen, The Man without a Face: The Unlikely Rise of Vladamir Putin. (London: Granta, 2012) p. 133.

${ }^{24}$ See Lynn Corum's Chapter on Project Russia in this book. 
${ }^{25}$ For an analysis of Russia's media campaign against small neighbors see Nerijas Maliukevicius, "Russia's Information Policy in Lithuania: The Spread of Soft Power of Information Geopolitics?" Baltic Security and Defence Review vol. 9 2007, pp. 150-170.

${ }^{26}$ On Russia's approach to soft power and information see Robert Ortturg, "Russia's Use of PR as a Foreign Policy Tool," Russian Analytical Digest 81, June 2010, pp. 7-10. See also "Russia's World”- Russia's Soft Power Approach to Compatriot's Policy," Russian Analytical Digest 81, June 2010, pp. 2-4

${ }^{27}$ Valters Nollendorfs, Dzintra Burg,; Gundega Michele, and Uldis Neiburgs, The Three Occupations of Latvia 1941-1991. (Riga: Occupation Museum Association of Latvia,2008). p.37.

${ }^{28}$ See the CIA World Factbook for recent statistics on the ethnic makeup of the Baltic States. In Latvia the population is $59.3 \%$ ethnic Latvian, 27.8\% Russian, 3.6\% Belarusian, 2.5\% Ukrainian. 37.5\% of Latvians are Russian speakers. In Estonia 68.7\% of the population is ethnic Estonian and 25.6\% are Russian or Russian speakers.

${ }^{29}$ On the citizenship issue and ethnic friction see Andris Runcis, "The Citizenship Issue as a Creeping Crisis, " in Crisis Management in a Transitional Society: the Latvian Experience, pp. 61-97.

${ }^{30}$ Heiko Pääbo, "War of Memories" Explaining the 'Memorials War' in Estonia," Baltic Security and Defence Review, Vol. 10 2008. pp. 5-28.

${ }^{31}$ Ceslovas Laurinavicius, „The Role of History in the Relationship between Lithuania and Russia,“ in Lithuanian Annual Strateguc Review 2005 (Strategic Research Center: Vilnius, 2006) pp. 109-125.

${ }^{32}$ Leonid Karabeshkin, "Russian-Lithuanian Relations: Between Negative Perception Stereotypes and Pragmatic Cooperation, "in Lithuanian Annual Strategic Review 2006, (Strategic Research Center: Vilnius, 2007) pp. 65-83. See p. 82.

${ }^{33}$ As a teacher at Tartu University in Estonia I can add some of my own experience. From 2011 to 2014 I taught every year a graduate class of approximately 45 students who are mostly Estonian and include ethnic Russians as well as ethnic Estonians. The ethnic Russians can speak Estonian (although their English tends to be more fluent than their Estonian) and also tend to be employed by Estonian firms. That many ethnic Russians are able to meet the very high entrance standards of Tartu University shows that the Estonian education system has not failed the ethnic Russian population. The ethnic Russians are fully included in the university life. Some of my ethnic Russian students have told me of visiting their relatives in Russia, but they seem to have little interest in becoming Russian citizens or to hold a deep attachment to the Russian state. The ethnic Estonian relationship to Russia seems to be more of a connection with their cousins back in the old country. Sometimes my ethnic Russian students note that they have been brought up to speak a Moscow (more educated) form of Russian, while their relations in Russia sometimes speak local dialects that are hard for them to understand.

${ }^{34}$ On the cyber-attacks on Estonia see Robert Ashmore, "Impact of Alleged Russian Cyber Attacks," Baltic Security and Defence Review, vol. 11. 2010, pp. 4-39.

35 (ITAR-TASS April 9, 2013.)

${ }^{36}$ Alexandr Dugan, From an interview to the Russian DELFI in Lithuania - November 2010.

${ }^{37}$ See The Military Doctrine of the Russian Federation, Approved by Russian Federation Presidential Edict on 5 February 2010. Translation by the SRAS- School of Russian and Asian Studies. The Main external threats to the Russian Federation are as follows: "8: The main external military dangers are:

a) the desire to endow the force potential of the North Atlantic Treaty Organization (NATO) with global functions carried out in violation of the norms of international law and to move the military infrastructure of NATO member countries closer to the borders of the Russian Federation, including by expanding the bloc; $b$ ) the attempts to destabilize the situation in individual states and regions and to undermine strategic stability; c) the deployment (buildup) of troop contingents of foreign states (groups of states) on the territories of states contiguous with the Russian Federation and its allies and also in adjacent waters..."

${ }^{38}$ Gediminas Vitkus, Jurate Novagrockiene, “The Impact of Lithuania on EU Council Decision-Making,” in Lithuanian Annual Strategic Review 2007 (Vilnius: Strategic Research Center, 2007) pp. 91-123.

${ }^{39}$ For a detailed overview of the Baltic leaders and their view on security see James S. Corum, The Security Concerns of the Baltic States as NATO Allies (Carlisle PA: US Army War College, Strategic Studies Institute, 2013)

${ }^{40}$ The Baltic Defence College was part of this lobby effort in hosting a workshop on the New NATO Strategic concept that featured leading Baltic politicians and academics. The proceedings of the workshop featured the need to 
maintain collective security as the key NATO strategy and discussed the perception of the Russian threat to NATO. See Proceedings of a Workshop on NATO's Strategic Concept, 15-16 October 2009, Tartu Estonia. Published in the Baltic Security and Defence Review, Vol. 12, Issue 1, 2010. 